\title{
Local development challenge in lagging-behind areas: insights from new \& evolutionary economic geography
}

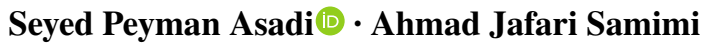

Accepted: 16 February 2022 / Published online: 4 March 2022

(C) The Author(s), under exclusive licence to Springer Nature B.V. 2022

\begin{abstract}
Lagging-behind regions, as an example of the failure of convergence in a country, has attracted the attention of many researchers who are attempting to adopt applicable policies and strategies to overcome the problem of low growth paths. The present study focuses on the policy proposals in the context of new economic geography and evolutionary economic geography for lagging-behind areas. Industrial agglomeration, as an essential element of the new economic geography, has restricted the potential for policy-making in lagging-behind regions. Creating regional advantages, as a policy in evolutionary economic geography, has provided diversified policy options for lagging-behind regions. However, this approach faces multi-level challenges in laggingbehind regions, including the lack of critical mass about low diversity and the gap in the knowledge base between lagging-behind and affluent areas. Therefore, if this policy is to be the basis for creating regional objectives, it should provide a structure for simulating external knowledge links and distinguishing the nature of the various related industries.
\end{abstract}

S. P. Asadi $(\bowtie) \cdot$ A. Jafari Samimi

University of Mazandaran, Babolsar, Iran

e-mail: Peymman.asadi@gmail.com

A. Jafari Samimi

e-mail: Jafarisa@umz.ac.ir
Keywords Lagging-behind regions $\cdot$ Development strategy $\cdot$ New economic geography $\cdot$ Evolutionary economic geography $\cdot$ Innovation

JEL Classification $\mathrm{R} 11 \cdot \mathrm{R} 12 \cdot \mathrm{R} 58$

\section{Introduction}

Convergence failure, characterized as inequality within countries and regional disparity in terms of income and employment, has received much attention in recent years in developing and developing countries (Iammarino et al., 2018). Although aggregate indicators suggest a positive image in macroeconomic performances, at the regional level, they show a different perspective in which some groups are lagging behind (Bussolo et al., 2018).

Since the late 1970s, the "new geography of jobs" shows that globalization and technological changes have affected many affluent rural areas through job losses, lower per capita incomes, and labor force participation compared to the national average (Moretti, 2012). During the 1990s and early 2000s, strong empirical evidence is available to support the fact that even though income disparity among countries has somewhat declined (Sala-i-Martin, 2006), this has not happened within countries and the gap between the poorer regions and ones with higher income has increased even further. Global development has been accompanied by a paradoxically parallel status, 
namely, "The Great Convergence" between countries (Baldwin, 2016) and at the same time "The Great Divergence" within countries (Moretti, 2012) among several industrialized economies.

Since 2011, there have been signs of reducing disparities within countries but it remains high in several respects such as significant regional productivity gap and the concentration of income and job opportunities in major cities and specific regions (OECD, 2018a). In the case of the European community, economic integration has not successful enough to reduce within-country disparity (Charron, 2016), intensifying it even after financial crises and sovereign debt period (Fratesi \& Rodríguez-Pose, 2016) and most recently COVID-19 pandemic (Irlacher \& Koch, 2021). Also, empirical evidence indicates that structural changes in inequality from individuals to groups results in the support of extreme political parties by inhabitants of lagging regions to express their dissatisfaction (Bussolo et al., 2018).

Consequently, the rising populism all over Europe (Ballas et al., 2017), anti-EU voting (Dijkstra et al., 2018), and Brexit superiority vote (Toly, 2017) are the very backlashes of such regional inequalities.

Attention to regional development strategy was revisited during the global financial crisis in 2008, and policymakers began to think of the most appropriate ways to boost growth and development. The main reason comes from the fact that during the second half of the $20 \mathrm{~s}$, non-core regions began to account for an increasing share of economic growth across Europe and many OECD countries [(Stefanou, 2014); (Dijkstra, 2013)]. A wide range of major international organizations in recent years also put the spotlight on the underlying rationale, the functions, and the intended consequence of local and regional development strategies WorldBank (2009); EuropeanCommission (2017); OECDb (2018). Re-addressing this issue has led to more sophisticated regional policy-making strategies from simple core-periphery stories to the idea of sustainable and inclusive regional growth in the EU (McCann \& Ortega-Argilés, 2015), place-based regional policy in both developed (Dąbrowski, 2014) and developing countries (Shenoy, 2018), and place-sensitive (Iammarino et al., 2018) policies.

Theoretically, the traditional economic approach to the dispersion process is found in the neoclassical growth model in which interventions in favor of the less developed regions are not necessary. The idea is that congestion and high cost of production factors in large and wealthy regions along with perfect competition and factor mobility yield constant or decreasing return to scale which as a consequence provide diffusion of prosperity and convergence in the real regional income or means of spatial equilibrium (Glaeser, 2008). This interpretation was rejected by both New Economic Geography (NEG) and Evolutionary Economic Geography (EEG). Instead, they argue that agglomeration forces can be a dominant equilibrium in economic geography. However, NEG and EEG differ in their approaches and policy recommendations; for example, the NEG theory is more interested in space-neutral approaches while EEG tends to consider space as an important factor in regional development prescriptions.

In this paper, we try to clarify the regional policy implications of NEG and EEG for lagging-behind regions in a comparable framework. The next section of the paper deals with the evolution of regional development strategies focusing on lagging-behind regions to determine the position of these two approaches. The third section discusses the NEG and its implications for regional development policy. Section four includes a discussion of the EEG. Finally, we conclude in Section Five.

\section{Evolution of regional development strategies}

Until the 1970s, the mainstream regional policy that received a wide range of attention in Europe and North America was trying to attract new firms or re-establish the existing ones in specific sectors in a top-down organized redistributive system. To do so, the investment resources for infrastructures such as transportation systems were provided to help underperformed areas to increase physical accessibility to more prosperous areas (Varga, 2017). Beginning in the 1980s onwards, the drawbacks of this viewpoint in regional development were revealed when the emphasis on physical investment gave way to the importance of regional entrepreneurial activities, education, $\mathrm{R} \& \mathrm{D}$, and knowledge-intensive economy. The underlying idea was that such policies contribute to regional convergence in two main ways. First, they enhance economic efficiency by focusing on maximizing agglomeration, and secondly, such policies 
counteract the negative impacts of agglomeration. The latter contribution is achieved by helping people become skilled or entrepreneurial as well as by ensuring the geographical mobility of labor and knowledge diffusion (Iammarino et al., 2018).

This so-called spatial-neutral (or people-based) approach is supported by the new economic geography and some other discourses, such as urban economics, in which regional policy advocates unbalanced economic growth and argues that due to lack of resources, promoting growth is not possible everywhere, so it is best to focus on cultivating dynamism in a few selected areas. In other words, policy should focus on selecting some areas to be dynamic in terms of economic performance and then ensuring that people have access to opportunities in these areas (Rodríguez-Pose, 2018). Not surprisingly, these approaches not only have limited success in reducing regional disparities but are based on the view that regional disparities are necessary and inevitable for overall economic performance [(Rodríguez-Pose \& Wilkie, 2019); (WorldBank, 2009)]. These policy procedures for under-performed areas are limited to temporary compensation for the mobility of people toward the agglomerated economic core (Pike et al., 2017).

The idea of space-neutral interventions is backed up by two most influential studies of WorldBank (2009) Report "Reshaping Economic Geography" and Sapir report (2004) "An Agenda for a Growing Europe". Both studies share the idea of space-neutral interventions, but the difference is that in the latter there is no economic geography per se and the emphasis is on sectoral policies.

Regardless of some successful cases of space-neutral policies such as the Appalachian Regional Commission in the United States and EU Structural Funds in Ireland (WorldBank, 2009), it seems that the overall accomplishment of the strategy in regional convergence is not significant. For example, EU Cohesion Policy did not considerably contribute to the reduction of regional disparity, although the policy had positive effects on the country-level growth (Fratesi and Wishlade (2017); Mohl (2016)).

Space-neutral policies have been questioned by the proponents of place-based (or space-based) policies for several empirical and theoretical reasons. The idea comes from the evidence of now leading but once lagging areas such as Asian Dragons, Flanders in Belgium, Southern Germany, and Las Vegas in the US and also the existence of some declined agglomerations in a series of industrial sectors such as Detroit and Buffalo in the US, Charleroi in Belgium, and Katowice in Poland (Rodríguez-Pose, 2018). Other reasons that undermine the spill-over mechanism of space-neutral policies to lagging-behind areas are the diminishing strength of agglomeration forces after the so-called Williamson curve (Varga, 2017), barriers associated with the high levels of mobility of production factors (Partridge et al., 2015) and the region-specific and localized resources for innovation and industrial application of new technologies (Varga \& Horváth, 2015). Furthermore, the existence of many large consumer cities in developing countries that depend on the export of raw materials has challenged the idea of agglomerations as the fundamental engine of growth [(Frick \& Rodríguez-Pose, 2018); (Gollin et al., 2016)].

Place-based development approaches endorse the importance of agglomeration in economic growth and argue that, in terms of its social, cultural, and institutional characteristics, geographical context matters in promoting sustainable development. The competition between space-neutral and space-based policies is partly the result of the old debate about whether development should be about places or people (Barca, et al., 2012). Indeed, since the two approaches acknowledge the importance of each other, their real point of difference is more related to the relative importance of the various tools in a set of desirable policy combinations based on the different place-specific circumstances [(Varga, 2017); (Garcilazo, et al., 2015)].

In the following two reports, the place-based approach provides convenient ways to demonstrate regional potentials and social inclusion. The independent Barca (2009) report: "An Agenda for a Reformed Cohesion Policy" and OECD (2009a) report: "Regions matter", which goes beyond "onesize-fits-all" development policies, stress the point that opportunities for growth exist in every region. This idea was followed by; they utilized the sectorial concept of smart specialization in a regional framework to provide a breakthrough in the European Union cohesion policy. However, some implications threaten place-based policies. Among them, the strong tendency of knowledge to concentrate in prosperous areas rather than on the spatial spillover 
toward lagging-behind regions (Dunford \& Smith, 2000), weak labor mobility in terms of skill-biased technological changes and uneven distribution of knowledge-intensive economic activities (Iammarino \& McCann, 2006), which lead to the relocation of labor away from such areas and the limited diffusion of innovation to them. Such a strong market mechanism alongside the equity-efficiency problem is likely to weaken many place-based policies. Furthermore, some studies argue that place-based policies might provide the possibility of national versus local welfare trade-off (Kline \& Moretti, 2014).

The other distinguished type of regional development policy is distributed development or placesensitive policy called by Iammarino et al. (2018) who claims to have some solutions. Space-neutral policies emphasizing efficiency through agglomeration squeeze the importance of regional equity while space-based policies considering territorial inequity, function more socially than the economic development strategy. Place-sensitive or distributed development tries to pursue efficiency and equity simultaneously by focusing on dynamic efficiency and the need for more agglomeration in as many places as possible.

Regional development policy approaches have recently become more diverse due to different configurations of recession in some areas. For instance, rural areas in Eastern Germany, Central-Eastern Europe, and also the Baltic States show a longlasting economic, social and demographic decline (Lang et al., 2015). Some researchers argue that policies that are largely growth-oriented and based on the dual categories of core-peripheral and metropolitan versus non-metropolitan spaces do not have a strong ability to capture local realities in these areas. These policies should go beyond the need to grow in non-nuclear areas and address this issue from a "social constructivist perspective" (Leick \& Lang, 2018). Growing heterogeneity among noncore regions, where almost half of Europe's population lives, highlights the need to reconsider the theoretical understanding of growth and development and regional policies in practice. In this context, some studies such as Smetkowski (2018) argue that lagging-behind and rural areas in Europe need a different strategy as EU-based growth policies are well suited for core agglomerated areas in Western Europe.
NEG: empirics, development and policy relevance

Since the seminal Core-Periphery model of Krugman, NEG has been developing for two decades and has paved the way to a mature conceptual framework by drawing much attention from mainstream economics. Developed in 1991, the NEG model was rapidly criticized and then modified within the field. The first criticism was the model's bias towards full agglomeration, as it depends solely on the cost of transportation, which is just one set of theories of agglomeration economies. Since transport costs fall below the threshold amount, full agglomeration would be the inevitable result. The one-size-fits-all approach in the initial NEG and the imprecise treatment with geography have also been criticized. Furthermore, the hypothesis of two regions with ambiguous entities and history as the initial condition is critically restrictive (Garretsen \& Martin, 2010).

Later, attempts were made to remove the agglomeration bias in the basic NEG model by including non-tradable sectors such as housing as additional spreading factors, capital, and intermediate goods as additional inputs, or moderation of the assumption of interregional labor mobility. In addition, some NEG studies targeted a specific level of geographical unit casting light on the importance of spatial scale (Combes et al., 2008).

Another line of criticisms addressed the specific modelling assumptions in NEG such as the DixitStiglitz assumption of monopolistic competition and numerical simulations. This downside was addressed in the second generation of NEG models by allowing alternative utility, demand, and production functions [(Ottaviano et al., 2002); (Forslid \& Ottaviano, 2003)]. In this regard, there are also studies such as Baldwin and Martin (2004) that tried to generate NEG growth models by combining the concepts of endogenous growth theory and the NEG model.

The overall focus of the NEG models was on the various types of spatial economic agglomeration than on policy relevance; however, Krugman (1991b) mentions some potential policy implications of NEG, especially for the European Monetary Union. Later, the policy implications stood at the center of analyses in NEG researches (Baldwin et al., 2011) and the policy-makers became more interested in regions and cities as significant factors in competitiveness and economic growth. Agglomeration and the NEG type 
models were also used in the policy suggestions of prominent policy-making organizations like WorldBank (2009), European Commission (2009), OECD (2009b) and the UK Treasury (2007).

Analyzing the NEG policy has some clear implications for the lagging-behind areas based on its tendency towards full agglomeration. First, it identifies unbalanced economic growth and emphasizes large and affluent areas; and second, it sets the primary policy goal of moving people to places with more opportunities rather than shifting opportunities to laggingbehind areas (WorldBank, 2009). In other words, this approach focuses more on people-based policies in which attention to lagging-behind areas is inefficient at best and diverts the need for structural changes at worst (Partridge et al., 2015). Therefore, any regional policies emphasizing balanced growth might face a regional equity-national efficiency trade-off. Namely, in the NEG framework, any policy aimed at reducing spatial concentration and regional disparity might have a devastating effect on national growth [see, for example, Baldwin et al. (2011)]. This implies that policies are in favour of strengthening spatial agglomeration while pursuing the policy of reducing interregional or intraregional disparities is unnecessary and inefficient from a national growth point of view in the NEG model. As an example, the spatial agglomeration or the unbalanced development strategy for boosting national growth in developing countries was recommended by the World Bank's 2009 Development Report.

There are some ambiguities in the empirical evidence, which are mostly based on the studies of European regional disparities. While a group of NEGtype studies proposes a direct relationship between national growth and the degree of spatial agglomeration or regional disparity [(Crozet \& Koenig, 2005); (Treasury, 2007)], others fail to find any significant relationships [(Bosker, 2007); (Martin, 2008); (Gardiner et al., 2010)]. Regarding this ambiguity, Krugman (2009) also cast some doubt on whether internal increasing returns to agglomeration are as crucial as they used to be. Furthermore, studies like Fingleton (2010) have proposed that models that emphasize spatial interdependencies in general and NEG models, in particular, are stronger at higher geographic scales, such as the country level.

The ambiguity of the NEG approach has also been observed in the studies of stability in the face of historical shocks. The main question about the investigation of initial equilibrium stability of regional distribution is that whether the system backs to its initial equilibrium after a shock happens. It is a matter of testing for the existence of multiple equilibria and hysteresis effects. The allied bombing of Japan and Germany during WWII, the US bombing of Vietnam, the bubonic plague in medieval Italy, and division and reunion of Germany are some samples of shocks that have been considered to assess the existence of multiple equilibria [(Garretsen \& Martin, 2010); (Redding, 2010)]. Davis and Weinstein $(2002,2004)$ considered the effect of the WWII bombing of Japan on the growth of the cities in the post-WWII period. Maarten Bosker et al. (2007) studied the effect of allied bombing WWII in Germany on their post-war development. The general findings of such studies are not in favor of multiple equilibria, as the city's growth returns to its "pre-shock" level over time.

In the case of sustainable growth and competitiveness, the capacity of regions for innovation has been considered a fundamental factor. New economic geography views the industrial agglomeration as the conceptual cornerstone of economic activity in general and of knowledge and innovation promotion at the regional level in particular. On this detail, the definition of agglomerated industry is a geographic concentration of firms in interrelated industries that compete and cooperate in creating spillover of knowledge and competence (Eklinder-Frick \& Åge, 2017), which provides the opportunity for local actors to communicate and facilitate innovation by learning processes (Hertog et al., 2001). Social capital also plays an important role in the dispersal of knowledge among regional actors, which is a basic prerequisite for innovation (Martin \& Moodysson, 2013). The interrelationships among industry agglomeration, social capital, knowledge, and innovation reveal the fundamentals of NEG in association with the regional policy.

This interpretation of NEG has been adopted by the European Commission as the cluster policy in creating industry agglomerations to achieve innovative behavior (EU Commission, 2008). Although the cluster model and industrial agglomeration have been widely criticized as the basis for a regional development strategy, the main dissatisfaction is with the definition of knowledge and innovation. In empirical studies, corporate investment in research 
and development and the number of patents are usually used as indicators of innovation in the regions (Srholec \& Verspagen, 2012). Such simplistic measurements of innovation attract many criticisms; for example, those who are geographers argue that such a conceptualization fails to recognize the non-linearity among the innovation process and $R \& D$ investments.

Overall, some argue that NEG has its limits and would not be easy to apply to empirical evaluation but its insights offer important theoretical guidance and make the NEG models better in ex-ante estimates of potential policy impacts (Potter, 2009). Krugman is aware of the methodological limitations of NEG (Krugman, 2011) but regarding policy implications, he argues that the formal abstract modelling of NEG is a methodological approach to 'what if' type questions. He also suggests that this general abstract formal modelling is more appropriate to ask and answer such questions than a case-study approach and the simplicity of formal modelling of NEG is a primary advantage that represents the complexity of the real world with only a few key parameters.

\section{EEG: theory, empirics, and regional development strategy}

Recognition of the importance of geography, space, and location in Krugman's new trade theory (1980) and new economic geography (1991a), (1991b) was not very impressive for the economic geographers. Despite the internal criticism of the NEG, like what is called theoretical strait-jacket (Behrens \& RobertNicoud, 2010), outside the field, geographers who dedicated themselves to Proper Economic Geography (Overman, 2004) and Evolutionary Economic Geography (Boschma \& Martin, 2007) also raised some related issues. They argue that the so-called new economic geography was not that new and was merely a modification of regional science, including abstract space and history. In addition, economic geographers have argued that combining the notion of equilibrium in NEG, even the multiple equilibria, and the evolutionary economic perspective is difficult as it reduces the capacity for endogenous self-transformation and change (Frenken \& Boschma, 2017).

Unlike NEG models in which decision-making is based on the utility maximization process, evolutionary approaches try to rely on the concept of routine behavior and bounded rationality. The beginning analyses in EEG starts with the black box of organizations in which they are competing with each other based on their routines. Routines can be understood as organizational features beyond the aggregation of individual skills. It includes experience knowledge (learning-by-doing) and tacit knowledge which are difficult to imitate by other firms (Teece et al., 1997) where there is no longer any reliance on the assumption of a representative agent. Having this variety paves the way for the selection process as an openended and out-of-equilibrium process of economic development (Hodgson, 1999).

Evolutionary economics tries to explain the usual distribution structure due to the process of selection forces and search behavior. Competition in the market is the tool of choice for diffusing the right routines and eliminating the bad ones. In other words, EEG figures out the spatial distribution of routines over time and is especially interested in diffusing new routines in space and investigating the forming process and mechanisms through which the diffusion of fitter routines occurs. Unlike NEG, spatial agglomeration and dispersion emergence analysis does not require rational location decisions (Frenken \& Boschma, 2017). In the EEG, more attention is paid to the emergence of a particular spatial perspective and its evolution in real historical time. This approach does not explain regional growth differences from a macro-micro perspective but focuses on the microhistories of firms operating in the territorial field. The evolutionary theory encompasses path-dependent processes in which past outcomes affect the likelihood of future outcomes, and current affairs are not determined solely by current circumstances; the current circumstances are limited by the previous affairs.

In this regard, many empirical studies have been conducted on the emergence and historical development of industries and technologies in different places, growth reduction, industrial expertise in specific regions and clusters, and the development and evolution of inter-firm and entrepreneurial networks. The importance of time and history in regional development studies has been recognized in this framework. A review of a 100-year range of US regional data to examine the relationship between different types of industrial links and co-agglomeration in the work of Diodato et al. (2018), 174 years of invention history in metropolitan areas in the United States in 
Mewes (2019), investigation of the Italian motorcycle industry from 1893 to 1993 in a study of the impact of spinoff generation events on the performance of parent organizations in Capone and Morrison (2020), and study of the 1850s to 1920 s to find out the nexus of migration and invention in the US in Morrison et al. (2018) are the examples of the growing interest in the historical empirical studies in the EEG.

The fundamental concept of regional policy implications in EEG rejects quadrilateral approaches: top-down, picking the winner, one-size-fits-all, and starting a policy from scratch (Boschma, 2009). In picking the winner policy, the policymaker targets a few specific sectors or regions, regardless of the risk of selecting the wrong region and wrong trajectory to move regions to a new direction [(Iammarino \& McCann, 2006); (Martin \& Sunley, 2006)].

One-size-fits-all regional policy is also no longer valid because of different regional characteristics like geographical location, institutional structure, and regional diversity. It suggests that the diversity of innovation potentials in different regions should be considered (Boschma, 2009). In regional policy, regional-specific endowments should be considered as a means of strengthening and expanding regional economic foundations instead of imitating successful policy models elsewhere (Asheim et al., 2011).

The regional history and background will determine the available options and the possible results of any policy. The starting point of regional policy should be the region's endowment, resources, specific requirements, and institutional background rather than starting from scratch (Lambooy \& Boschma, 2001). In addition, openness to new ideas, newcomers, and new policy trials increases the likelihood of effective policymaking and avoids regional lock-ins (Boschma, 2009).

It's important to note the role of networks in the development strategy of lagging behind areas. The interaction of geography and networks can be classified at least in two ways: First, 'place makes a difference' and second, 'proximity affects network formation' (Glückler, 2007). According to Storper and Venables (2004) and Marquis (2003), developments in transportation and communication technologies have reduced the impact of geography on economic relations and network formation. But the idea of "place makes a difference" emphasizes a place-specific resource profile that has implications for lagging behind areas, considering the characteristics such as low-knowledge intensity and medium-to-low skilled labor pool. Therefore, the policy should provide recommendations to stimulate external knowledge links, especially for industries that have high development costs, are knowledge-intensive, and require a relatively long period to expand into peripheral areas.

In the regional policy of EEG, Constructing Regional Advantages (CRA) is the main structure that focuses on the regional innovation policy. This approach stemmed from dissatisfaction with the European Commission's R\&D policy in the 2000s when the focus was on Research and Development (R\&D) to promote technology and innovation. The CRA argues that the innovation process is not a linear $\mathrm{R} \& \mathrm{D}$ process and that due to the high concentration of $R \& D$ in different regions, this policy will not be sufficient for all regions to strengthen technology and innovation (Cooke et al., 2006).

"Related variety", as the key concept of CRA, refers to the variety of industries in various regions that are cognitively interconnected (Frenken et al., 2007). This model offers an alternative regional innovation policy approach for each type of region, emphasizing the specific knowledge base of activities and their combination in regions (Boschma, 2014), while CRA argues that any region has its specific endowments and its source of diversification. Industrial agglomeration plays a crucial role in the development of regional innovation in NEG. However, innovation achievements without an industrial structure might not be significant. The NEG model, like the CRA, seems to be more implicitly related to the large well-off regions with a diversity of industrial sectors, however, empirical studies also show the relevance of CRA for small regions (Isaksen \& Karlsen, 2013).

The regional characteristics of policy recommendations and the EEG's "one size fits all" policy rejection in the CRA reveal the idea that the intangible assets of regions such as institutional settings, specific knowledge bases, and their geographical and industrial contexts are the starting point as they define the existing policy options and determine regional differences in existing specialties and knowledge bases.

The concept of Constructing Regional Advantage (CRA) and Smart specialization approach (SS) (McCann \& Ortega-Argilés, 2015), as key elements in the EU 2020 Innovation Plan and the reformed EU 
Cohesion Policy, have some similarities. Both are in favor of policy intervention in the regions aimed at identifying and prioritizing 'promising' targets with the idea of rejecting 'one-size-fits-all' policies, creating new activities in regions from scratch and adopting 'picking-the-winner' approaches. The focus of the identification process in SS is on entrepreneurship discovery, in which entrepreneurs choose future areas of expertise, while the CRA concept seeks to identify related diversity and barriers that prevent related industries from connecting and interacting in regions. Both approaches consider local stakeholder participation as a significant part of rent-seeking policy and behavior, corruption and lock-in as potential threats to their policies (Boschma, 2014). NEG also shares the idea of public-private collaboration in the regional innovation system with the concepts of SS and CRA.

\section{Discussion and concluding remarks}

Given the new trends of regional economic divergence over the past few years and their effects on economic development, as well as social and political stability, the importance of a sound regional development strategy has been re-examined.

Lack of opportunities in lagging-behind regions, growing larger populism, and regional implications for comprehensive growth are new challenges for optimal regional development policies. Aside from the neoclassical growth theory, which sees no need to interfere in the favor of less developed regions, other approaches demand rightful regional development policies. Supposing the idea of agglomeration economies as a central factor for overall economic performance, in urban economies and new economic geographies, it is recommended empowering the market mechanisms to extend prosperity and opportunity to non-agglomerated areas.

Given what has been said, the vital importance of location and geography and the scarcity of resources make the development strategy unbalanced with the ultimate goal of selecting several cores or agglomerated areas and moving people to those regions.

However, people-based policies have been challenged by some empirical evidence on such grounds as the growing significance of non-core regions in national economic growth in developed countries, the decline of some old agglomerations and the emergence of the new ones, and the restrictions placed on the geographical mobility of labor and knowledge diffusion. Nevertheless, the importance of agglomeration is still undeniable. This new status of regional development drives us to a more pluralistic approach as a regional development strategy.

Respecting the evolutionary economic geography and the appreciation of its regional policy within the framework of the CRA contribute to the diversity of policy options. The main idea of evolutionary economic geography is to reject 'one-sized-fits-all' policies and to propose the idea of "related variety ", which provides context-specific recommendations for each type of region.

The complexity of the analysis in the development of regional policy approaches has increased tremendously, and various methods try to portray as many factors as possible in their studies. The growing importance of incorporating institutional background and multilevel good governance is at the heart of recent approaches.

Increasing attention to innovation and technology and their positions in competitiveness and sustainable growth makes it difficult for NEG to apply development strategy in lagging-behind regions because industrial agglomeration in NEG is the cornerstone of economic activities and the main factor in promoting knowledge and innovation at the regional level.

The idea of 'smart specialization' and other 'related variety' reduces the importance of industrial agglomeration and, therefore, offers a more practical development strategy for lagging-behind regions as it provides opportunities for entrepreneurs to choose their future areas of expertise and identify related diversity. These approaches face multifaceted challenges, including the possibility of the existence of national versus local welfare trade-offs, rent-seeking behavior, corruption, and imprisonment.

Creating regional advantages, especially in peripheral areas, is not as easy as it seems in the CRA framework. There is a strong desire for knowledge and a highly skilled workforce to concentrate in core areas, and the unequal distribution of knowledgebased economic activities has always contributed to the gap between affluent and lagging-behind regions. In addition, the lack of critical mass of company and employment in the case of low related diversity, institutional environments and geographical features such 
as natural climate, further limits the development of new trends.

Considering the endowments of the regions as a criterion to create new routes reveals some problems because the structure of these areas is usually associated with features such as low-knowledge intensity and medium to the low-skilled workforce. Therefore, policy should provide recommendations to stimulate external knowledge links, especially for industries that have high development costs, are knowledgeintensive, and require a relatively long period to expand into peripheral areas. The framework should reflect the different features of different related industries when it is to be the basis for constructing regional advantage.

Acknowledgements The authors are grateful to Jacques François Thisse, Martin Henning, and Andre Sapir for insightful comments and suggestions.

Data availability Data sharing not applicable to this article as no datasets were generated or analyzed during the current study.

\section{Declarations}

Conflict of interest The authors have no relevant financial or non-financial interests to disclose.

Consent for publication All authors consent to participate and publication of the article.

\section{References}

Asheim, B. T., Boschma, R., \& Cooke, P. (2011). Constructing regional advantage: Platform policies based on related variety and differentiated knowledge bases. Regional Studies, 45(7), 893-904.

Baldwin, R., \& Martin, P. (2004). Agglomeration and regional growth. In J. Vernon Henderson \& J. -F. Thisse (Eds.), Handbook of regional and urban economics (Vol. 4, pp. 2671-2711). Elsevier.

Baldwin, R., Forslid, R., Martin, P., Ottaviano, G., \& RobertNicoud, F. (2011). Economic geography and public policy. Princeton University Press.

Baldwin, R. (2016). The great convergence. Harvard University Press.

Ballas, D., Dorling, D., \& Hennig, B. (2017). Analysing the regional geography of poverty, austerity and inequality in Europe: A human cartographic perspective. Regional Studies, 51(1), 174-185.

Barca, F. (2009). An Agenda for a reformed cohesion policy. A place-based approach to meeting EU challenges and expectations. Independent Rep. to D. Hubner. Bruxelles: Commissioner of regional policy.

Barca, F., McCann, P., \& Rodríguez-Pose, A. (2012). The case for regional development intervention: Place-based versus place-neutral approaches. Journal of Regional Science, 52(1), 134-152.

Behrens, K., \& Robert-Nicoud, F. (2010). Tempora mutantur: In search of a new testament for NEG. Journal of Economic Geography, 11(2), 215-230.

Boschma, R., \& Martin, R. (2007). Constructing an evolutionary economic geography. Oxford University Press.

Boschma, R. (2009). Evolutionary economic geography and its implications for regional innovation policy. Papers in Evolutionary Economic Geography, 9(12), 1-33.

Boschma, R. (2014). Constructing regional advantage and smart specialisation: Comparison of two European policy concepts. Scienze Regionali, 2014(1), 51-68.

Bosker, M. (2007). Growth, agglomeration and convergence: A space-time analysis for European regions. Spatial Economic Analysis, 2(1), 91-100.

Bosker, M., Brakman, S., Garretsen, H., \& Schramm, M. (2007). Looking for multiple equilibria when geography matters: German city growth and the WWII shock. Journal of Urban Economics, 61(1), 152-169.

Bussolo, M., Davalos, M. E., Peragine, V., \& Sundaram, R. (2018). Toward a new social contract: Taking on distributional tensions in Europe and Central Asia. The World Bank.

Capone, G., \& Morrison, A. (2020). Spinoffs and parents in clusters: Evidence from the Italian motorcycle industry. Industry Innovation, 27(10), 1133-1159.

Charron, N. (2016). Diverging cohesion? Globalisation, state capacity and regional inequalities within and across European countries. European Urban and Regional Studies, 23(3), 355-373.

Combes, P.-P., Mayer, T., \& Thisse, J.-F. (2008). Economic geography: The integration of regions and nations. Princeton University Press.

Commission, E. (2008). Towards world-class clusters in the European Union: Implementing the broad-based innovation strategy. 652 .

Commission, E. (2009). Paul Krugman's new economic geography: Past, present and future. Bureau of European policy advisors seminar, European commission.

Cooke, P., Asheim, B., Annerstedt, J., Blazek, J., Boschma, R., Brzica, D., \& Moula, M. (2006). Constructing regional advantage: Principles perspectives, policies. DG Research.

Crozet, M., \& Koenig, P. (2005). The Cohesion vs growth tradeoff-evidence from EU regions (1980-2000).

Dąbrowski, M. (2014). Towards place-based regional and local development strategies in central and eastern Europe? EU cohesion policy and strategic planning capacity at the subnational level. Local Economy, 29(4-5), 378-393.

Davis, D. R., \& Weinstein, D. E. (2002). Bones, bombs, and break points: The geography of economic activity. American Economic Review, 92(5), 1269-1289.

Den Hertog, P., Bergman, E., \& Charles, D. (2001). Innovative clusters: Drivers of national innovation policy. OECD Publishing. 
Dijkstra, L., Poelman, H., \& Rodrìguez, P. A. (2018). The Geography of EU discontent Europena commision, regional and urban policy working paper, 12/2018.

Dijkstra, L. (2013). Why investing more in the capital can lead to less growth. Cambridge Journal of Regions, Economy Society, 6(2), 251-268.

Diodato, D., Neffke, F., \& O'Clery, N. (2018). Why do industries coagglomerate? How Marshallian externalities differ by industry and have evolved over time. Journal of Urban Economics, 106, 1-26.

Dunford, M., \& Smith, A. (2000). Catching up or falling behind? Economic performance and regional trajectories in the "New Europe." Economic Geography, 76(2), 169-195.

Eklinder-Frick, J., \& Åge, L.-J. (2017). Perspectives on regional innovation policy-From new economic geography towards the IMP approach. Industrial Marketing Management, 61, 81-92.

EuropeanCommission. (2017). Competitiveness in low-income and low-growth regions. The lagging regions report. Brussels, 10.4.2017 SWD(2017) 132 final.

Fingleton, B. (2010). The empirical performance of the NEG with reference to small areas. Journal of Economic Geography, 11(2), 267-279.

Forslid, R., \& Ottaviano, G. (2003). An analytically solvable core-periphery model. Journal of Economic Geography, 3(3), 229-240.

Fratesi, U., \& Wishlade, F. G. (2017). The impact of European cohesion policy in different contexts. Regional Studies, Editorial, 51(6), 817-821.

Fratesi, U., \& Rodríguez-Pose, A. (2016). The crisis and regional employment in Europe: What role for sheltered economies? Cambridge Journal of Regions, Economy and Society, 9(1), 33-57.

Frenken, K., \& Boschma, R. A. (2017). Why is economic geography not an evolutionary science? Towards an evolutionary economic geography. In J. Agnew \& R. Martin (Eds.), Economy (pp. 127-156). Routledge.

Frenken, K., Van Oort, F., \& Verburg, T. (2007). Related variety, unrelated variety and regional economic growth. Regional Studies, 41(5), 685-697.

Frick, S. A., \& Rodríguez-Pose, A. (2018). Big or small cities? On city size and economic growth. Growth and Change, 49(1), 4-32.

Garcilazo, E., Martins, J., \& Tompson, W. (2015). The modern regional policy paradigm: Rationale and evidence from OECD countries. GOT, Revista De Geografia e Ordenamento Do Território, 1(7), 9-44.

Gardiner, B., Martin, R., \& Tyler, P. (2010). Does spatial agglomeration increase national growth? Some evidence from Europe. Journal of Economic Geography, 11(6), 979-1006.

Garretsen, H., \& Martin, R. (2010). Rethinking (new) economic geography models: Taking geography and history more seriously. Spatial Economic Analysis, 5(2), 127-160.

Glaeser, E. L. (2008). Cities, agglomeration, and spatial equilibrium. Oxford University Press.

Glückler, J. (2007). Economic geography and the evolution of networks. Journal of Economic Geography, 7(5), 619-634.
Gollin, D., Jedwab, R., \& Vollrath, D. (2016). Urbanization with and without Industrialization. Journal of Economic Growth, 21(1), 35-70.

Hodgson, G. M. (1999). Evolution and institutions. Books.

Iammarino, S., Rodríguez-Pose, A., \& Storper, M. (2018). Regional inequality in Europe: Evidence, theory and policy implications. Journal of Economic Geography., 19(2), 273-298.

Iammarino, S., \& McCann, P. (2006). The structure and evolution of industrial clusters: Transactions, technology and knowledge spillovers. Research Policy, 35(7), 1018-1036.

Irlacher, M., \& Koch, M. (2021). Working from home, wages, and regional inequality in the light of COVID-19. Jahrbücher Für Nationalökonomie Und Statistik, 241(3), 373-404.

Isaksen, A., \& Karlsen, J. (2013). Can small regions construct regional advantages? The Case of Four Norwegian Regions, 20(2), 243-257. https://doi.org/10.1177/09697 76412439200

Kline, P., \& Moretti, E. (2014). People, places, and public policy: Some simple welfare economics of local economic development programs. Annual Review of Economics, 6(1), 629-662.

Krugman, P. (1980). Scale economies, product differentiation, and the pattern of trade. American Economic Review, 70(5), 950-959.

Krugman, P. (1991a). Increasing returns and economic geography. Journal of Political Economy, 99(3), 483-499.

Krugman, P. (1991b). Geography and trade. MIT Press.

Krugman, P. (2009). How did economists get it so wrong? New York times, 2(9), 2009.

Krugman, P. (2011). The new economic geography, now middle-aged. Regional Studies, 45(1), 1-7.

Lambooy, J. G., \& Boschma, R. A. (2001). Evolutionary economics and regional policy. Annals of Regional Science, 35(1), 113-131.

Lang, T., Henn, S., Ehrlich, K., \& Sgibnev, W. (2015). Understanding geographies of polarization and peripheralization: Perspectives from central and Eastern Europe and beyond. Springer.

Leick, B., \& Lang, T. (2018). Re-thinking non-core regions: Planning strategies and practices beyond growth. European Planning Studies, 26(2), 213-228.

Marquis, C. (2003). The pressure of the past: Network imprinting in intercorporate communities. Administrative Science Quarterly, 48(4), 655-689.

Martin, R. (2008). National growth versus spatial equality? A cautionary note on the new 'trade-off'thinking in regional policy discourse. Regional Science Policy Practice, 1(1), $3-13$.

Martin, R., \& Moodysson, J. (2013). Comparing knowledge bases: On the geography and organization of knowledge sourcing in the regional innovation system of Scania Sweden. European Urban Regional Studies, 20(2), 170-187.

Martin, R., \& Sunley, P. (2006). Path dependence and regional economic evolution. Journal of Economic Geography, 6(4), 395-437.

McCann, P., \& Ortega-Argilés, R. (2015). Smart specialization, regional growth and applications to European Union cohesion policy. Regional Studies, 49(8), 1291-1302. 
Mewes, L. (2019). Scaling of atypical knowledge combinations in American Metropolitan areas from 1836 to 2010. Economic Geography, 95(4), 1-21.

Mohl, P. (2016). Econometric evaluation of EU cohesion policy: a survey. In P. Mohl (Ed.), Empirical evidence on the macroeconomic effects of EU cohesion policy (pp. 7-35). Springer.

Moretti, E. (2012). The new geography of jobs. Houghton Mifflin Harcourt.

Morrison, A., Petralia, S., \& Diodato, D. (2018). Migration and invention in the age of mass migration, papers in evolutionary economic geography.

OECD. (2009a). Regions matter: Economic recovery, innovation and sustainable growth. Organisation for Economic Co-operation and Development.

OECD. (2009b). How regions grow: Trends and analysis. Organisation for Economic Co-operation and Development Paris.

OECD. (2018). OECD Regions and cities at a glance. OECD Publishing.

OECD. (2018). Rethinking regional development policymaking, OECD multi-level governance studies. OECD Publishing.

Ottaviano, G., Tabuchi, T., \& Thisse, J. F. (2002). Agglomeration and trade revisited. International Economic Review, 43(2), 409-435.

Overman, H. G. (2004). Can we learn anything from economic geography proper? Journal of Economic Geography, 4(5), 501-516.

Partridge, M. D., Rickman, D. S., Olfert, M. R., \& Tan, Y. (2015). When spatial equilibrium fails: Is place-based policy second best? Regional Studies, 49(8), 1303-1325.

Pike, A., Rodríguez-Pose, A., \& Tomaney, J. (2017). Shifting horizons in local and regional development. Regional Studies, 51(1), 46-57.

Potter, J. (2009). Evaluating regional competitiveness policies: Insights from the new economic geography. Regional Studies, 43(9), 1225-1236.

Redding, S. (2010). The empirics of new economic geography. Journal of Regional Science, 50(1), 297-311.

Rodríguez-Pose, A., \& Wilkie, C. (2019). Strategies of gain and strategies of waste: What determines the success of development intervention? Progress in Planning, 133, 100423 .

Rodríguez-Pose, A. (2018). The revenge of the places that don't matter (and what to do about it). Cambridge Journal of Regions, Economy Society, 11(1), 189-209.

Sala-i-Martin, X. (2006). The world distribution of income: Falling poverty and... convergence, period. The Quarterly Journal of Economics, 121(2), 351-397.
Sapir, A., Aghion, P., Bertola, G., Hellwig, M., Pisani-Ferry, J., Rosati, D., \& Nava, M. (2004). An agenda for a growing Europe: The Sapir report. OUP.

Shenoy, A. (2018). Regional development through place-based policies: Evidence from a spatial discontinuity. Journal of Development Economics, 130, 173-189.

Smetkowski, M. (2018). The role of exogenous and endogenous factors in the growth of regions in central and Eastern Europe: The metropolitan/non-metropolitan divide in the pre-and post-crisis era. European Planning Studies, 26(2), 256-278.

Srholec, M., \& Verspagen, B. (2012). The Voyage of the Beagle into innovation: Explorations on heterogeneity, selection, and sectors. Industrial Corporate Change, 21(5), 1221-1253.

Stefanou, S. (2014). Promoting growth in all regions. European Review of Agricultural Economics, 41(1), 173-175.

Storper, M., \& Venables, A. (2004). Buzz: Face-to-face contact and the urban economy. Journal of Economic Geography, 4(4), 351-370.

Teece, D. J., Pisano, G., \& Shuen, A. (1997). Dynamic capabilities and strategic management. Strategic Management Journal, 18(7), 509-533.

Toly, N. (2017). Brexit, global cities, and the future of world order. Globalizations, 14(1), 142-149.

Treasury, H. (2007). Regional disparities and growth in Europe.

Varga, A., \& Horváth, M. (2015). Regional knowledge production function analysis. Handbook of research methods and applications in economic geography, 513

Varga, A. (2017). Place-based, spatially blind, or both? Challenges in estimating the impacts of modern development policies: The case of the GMR policy impact modeling approach. International Regional Science Review, 40(1), 12-37.

Weinstein, D. E., \& Davis, D. R. (2004). Search for multiple equilibria in urban industrial structure. Paper presented at the econometric society 2004 North American winter meetings.

WorldBank. (2009). Reshaping economic geography world development report. The World Bank.

Publisher's Note Springer Nature remains neutral with regard to jurisdictional claims in published maps and institutional affiliations. 